\title{
BUMN dan Unika Atma Jaya Bersinergi: Sandwich Pendampingan Karir Berkelanjutan dalam Program Magang Bersertifikat
}

\author{
Lisa Esti Puji Hartanti, Juneman Abraham*, Kartika Sumanto, Ignatius Prasetyo, Eko Susanto** \\ Biro Kemahasiswaan, Alumni, dan Pembimbingan Karir Mahasiswa, \\ Universitas Katolik Indonesia Atma Jaya \\ $\underline{\text { lisa.esti@atmajaya.ac.id }}$
}

\begin{abstract}
Abstrak
Employability-kemampuan untuk bekerja dan dipekerjakan-merupakan salah satu petunjuk penting tentang keberhasilan proses pendidikan di perguruan tinggi. Tidak dapat dipungkiri bahwa dewasa ini terdapat "tekanan" untuk pengembangan employability di perguruan tinggi sebagai wujud tuntutan masyarakat akan kualitas perguruan tinggi yang dapat dipertanggung jawabkan secara nyata. Unika Atma Jaya (UAJ) menyadari bahwa keragaman sudut pandang menjadikan employability sebuah sasaran yang sulit ditentukan. Menyadari kesulitan tersebut, UAJ khususnya Biro Kemahasiswaan, Alumni, dan Pembimbingan Karir Mahasiswa (BKAK) menggali data dari lapangan, yaitu lapangan lembaga pemberi kerja (yang menjadi partner UAJ dalam career fair, melalui sarana kuesioner), dan lapangan alumni UAJ sendiri yang telah menjadi yang terdepan dalam bidang profesinya (melalui diskusi kelompok terarah pada sebuah Malam Alumni). Eksplorasi ini dilakukan pada tahun 2018, baik secara kualitatif maupun kuantitatif. Penggalian data ini bertujuan untuk mengetahui secara lebih persis harapan-harapan yang menduduki frekuensi tertinggi sebagai atribut employability yang perlu dikembangkan secara khusus melalui jalur magang. Hasil penggalian memperlihatkan adanya tiga atribut employability teratas, yakni (1) Assertive communication and critical thinking (Kemampuan untuk mengungkapkan diri secara apa adanya namun penuh rasa hormat dan tidak khawatir menggunakan daya kritis), (2) Integrity (Kekuatan dan keberanian untuk bertindak benar sekalipun tidak ada dukungan), dan (3) Resilience (Daya lenting atau kapasitas untuk memulihkan diri dan bertumbuh dari pengalaman yang mengganggu dan menekan). Ringkasnya, diakronimkan sebagai "AIR". AIR diimplementasikan "secara sandwich" dalam bentuk program pendampingan magang berkelanjutan yaitu selama 6 bulan, dengan pertemuan sebulan sekali kepada mahasiswa yang sedang magang di BUMN. Bentuk kegiatan adalah pelatihan berupa input materi, aktivitas terkait tema, dan career coaching, serta kelompok sharing yang didampingi oleh alumni. Selama magang, mereka tidak dilepas begitu saja, tetapi ditemani dan diberikan bekal terkait dinamika dunia kerja. Hasilnya adalah mereka mendapatkan soft-skill terkait persiapan karir yang disinergikan pengalaman langsung di lapangan melalui magang.
\end{abstract}

Kata kunci: pendampingan magang, persiapan karir, employability, formasi berkelanjutan.

\footnotetext{
* Konsultan.

** Presenter/Penyaji di Universitas Mulawarman, Samarinda, 17-19 Oktober 2019 http://www.careercenter.id/iccn-summit-2019
}

File ini merupakan draf paper yang akan diterbitkan dalam Prosiding yang akan beralamatkan di http://www.careercenter.id/proceeding-iccn sebagai 


\section{Pendahuluan}

Employability - atau kemampuan untuk bekerja dan dipekerjakan - merupakan salah satu petunjuk penting tentang keberhasilan proses pendidikan di perguruan tinggi. Tidak dapat dipungkiri bahwa dewasa ini terdapat "tekanan" untuk pengembangan employability di perguruan tinggi sebagai wujud tuntutan masyarakat akan kualitas perguruan tinggi yang dapat dipertanggung jawabkan secara nyata.

Employability didefinisikan sebagai serangkaian pencapaian, keterampilan, pemahaman dan atribut pribadi, yang membuat lulusan lebih mungkin mendapatkan pekerjaan dan menjadi sukses dalam pekerjaan pilihan mereka, yang menguntungkan diri sendiri, tenaga kerja, masyarakat dan dunia ekonomi (Yorke, 2004: 410). Sudut pandang employability dapat diperoleh dari: majikan/ perusahaan/ lembaga pemberi kerja, mahasiswa/ calon lulusan, perguruan tinggi, dan masyarakat.

Unika Atma Jaya menyadari bahwa keragaman sudut pandang menjadikan employability sebuah sasaran yang sulit ditentukan. Setiap pihak memiliki persepsi dan aspirasinya masingmasing, dan karenanya prioritas pengembangan employability menjadi ambigu: Apakah hal yang penting dari atribut employability seorang calon lulusan adalah kepribadian ataukah keterampilan? Apabila yang pertama atau yang kedua, kepribadian atau keterampilan apa saja yang perlu dikembangkan, dan bagaimana mengembangkannya?

Litbang Kompas (2017), misalnya, memaparkan sebuah hasil analisis yang menyatakan bahwa kemampuan di bidang digital dan teknologi, berpikir kreatif dan eksperimentasi, serta analisis dan interpretasi data, merupakan tiga keterampilan teratas yang dibutuhkan dalam menghadapi era kecerdasan buatan. Lebih lanjut, Australian National University (2017) merumuskan delapan keterampilan yang menunjang employability seseorang dalam pekerjaan apapun, yakni (1) pengelolaan diri, (2) perencanaan dan pengorganisasian, (3) pemecahan masalah, (4) komunikasi, (5) kerja sama tim, (6) inisiatif dan enterprise, (7) belajar, dan (8) penggunaan teknologi. Apabila ada lembaga ketiga yang memaparkan rumusan lainnya, maka akan ditemukann tiga buah rumusan, dan seterusnya.

Apakah seluruh rumusan perlu diadopsi, menjadi pertanyaan abadi yang menggelayut dalam setiap universitas yang hendak mencita-citakan kualitas employability yang paling baik dan paling relevan bagi mahasiswa dan calon lulusannya.

Menyadari kesulitan tersebut, Unika Atma Jaya (UAJ) khususnya pada Biro Kemahasiswaan, Alumni, dan Pembimbingan Karir Mahasiswa (BKAK) menggali data dari lapangan, yaitu lapangan lembaga pemberi kerja (yang menjadi partner UAJ dalam cereer fair, melalui sarana kuesioner), dan lapangan alumni UAJ sendiri yang telah menjadi yang terdepan dalam bidang profesinya (melalui diskusi kelompok terarah pada sebuah Malam Alumni). Eksplorasi ini dilakukan pada tahun 2018, baik secara kualitatif yaitu dengan Diskusi Kelompok Terpumpun (Focus Group Discussion) maupun kuantitatif dengan kuesioner. Penggalian data ini bertujuan untuk mengetahui secara lebih persis harapan-harapan apa saja yang menduduki frekuensi tertinggi sebagai atribut employability yang perlu dikembangkan secara khusus melalui jalur magang.

Hasil penggalian memperlihatkan adanya tiga atribut employability teratas, yakni (1) Assertive communication and critical thinking (Kemampuan untuk mengungkapkan diri secara apa adanya namun penuh rasa hormat dan tidak khawatir menggunakan daya kritis), (2) Integrity (Kekuatan dan keberanian untuk bertindak benar sekalipun tidak ada dukungan), dan (3) Resilience (Daya lenting atau kapasitas untuk memulihkan diri dan bertumbuh dari pengalaman yang mengganggu dan menekan). Ringkasnya, diakronimkan sebagai "AIR".

Branding AIR dilakukan sesuai dengan kenyataan bahwa air (water) dalam bahasa Indonesia maupun air (udara) dalam bahasa Inggris merupakan zat yang maha-ada dalam kehidupan seorang manusia. Tanpa air, kehidupan seseorang di muka bumi tidak 
dimungkinkan. Demikianlah, krisis AIR berarti krisis dalam employability lulusan Unika Atma Jaya.

Pengembangan atribut AIR melalui jalur magang satu semester merupakan sebuah terobosan yang diselenggarakan oleh BKAK UAJ guna meningkatkan keterjaminan employability lulusan UAJ di lapangan. Melalui penambahan signifikan jumlah jam magang serta situasi pekerjaan riil, mahasiswa akan lebih mampu menghidupi AIR dalam pikiran, perasaan, dan perilaku profesionalnya sehari-hari.

Aktivitas yang dijalani akan menghadirkan pemahaman yang mendalam mengenai AIR serta kompetensi dalam menjawab, menghadapi, serta mengurus tantangan-tantangan nyata terhadap AIR dalam dunia profesi. AIR sebagai sebuah formulasi berbasis data lapangan akan menjadi fokus pengembangan mahasiswa calon lulusan, yang alam prosesnya didampingi oleh para mentor yang telah banyak menyelami dan memakan "asam-garam"-nya AIR.

Menyadari bobot dari program ini, BKAK UAJ menjadikannya sebagai pilot project Tahun 2019 dengan memberikan sertifikat AIRing Your Professional Life kepada para alumni program ini.

\section{Program Pendampingan Karir Berkelanjutan}

Berdasarkan penjelasan pendahuluan yang menjadi latar belakang program ini, aspek employability menjadi dasar dalam pelaksanaan program. Maka, tujuan dari program adalah untuk meningkatkan kemampuan employability calon lulusan Unika Atma Jaya dengan menggunakan tiga atribut yaitu (1) Assertive communication and critical thinking (Kemampuan untuk mengungkapkan diri secara apa adanya namun penuh rasa hormat dan tidak khawatir menggunakan daya kritis), (2) Integrity (Kekuatan dan keberanian untuk bertindak benar sekalipun tidak ada dukungan), dan (3) Resilience (Daya lenting atau kapasitas untuk memulihkan diri dan bertumbuh dari pengalaman yang mengganggu dan menekan). Secara ringkas, disebut "AIR" (lihat Gambar 1).

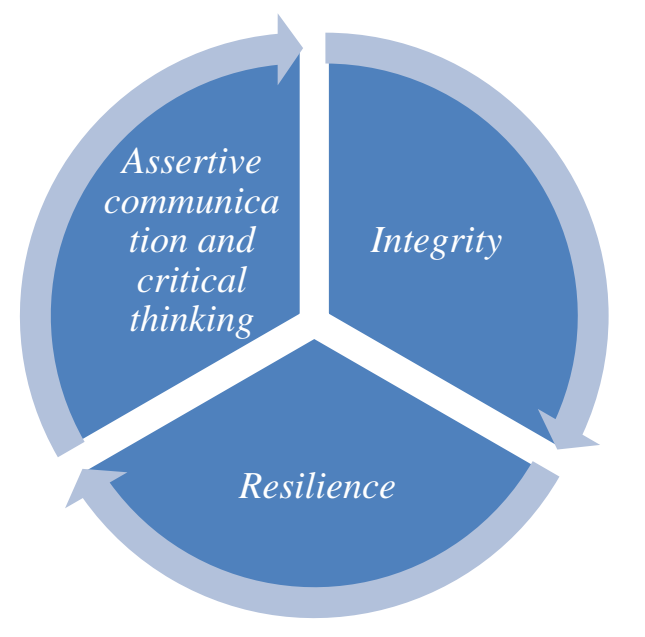

Gambar 1. Diagram Tiga Atribut Program Pendampingan Magang Berkelanjutan.

Ketiga atribut tersebut saling berhubungan satu sama lain dan melengkapi. Saat proses pemberian materi tentang komunikasi asertif, proses integritas (sebagai proses yang bukan menekankan pada sifat-sifat conscientiousness - kerapian, ketekunan, dan kedisiplinan, melainkan keberanian, kekuatan, konsistensi untuk menghubungkan prinsip dan nilai yang benar secara moral dan tindakan yang dilakukan meskipun ada risiko ketidakuntungan; Abraham \& Pane, 2014) dan daya lenting (sebagai proses membangkitkan diri kembali dari 
kesulitan, tekanan, dan kemalangan; Tano, Abraham, \& Sitorus, 2014) juga menjadi bagian yang dieksplorasi, namun porsi besar terdapat pada tema materi yang diberikan saat itu. Hal ini karena proses berkomunikasi secara asertif dan kritis dapat dipicu jika memiliki jiwa integritas, dan memiliki kemampuan adaptasi di lingkungan yang baru.

Ketiga atribut ini juga menjadi dasar dalam pembuatan kurikulum program pendampingan magang selama 6 bulan. Metode pendampingan meliputi pelatihan berupa input materi, aktivitas terkait tema, dan career coaching, serta kelompok sharing yang didampingi oleh alumni. Artinya, selama magang mereka tidak dilepas begitu saja, tetapi ditemani dan diberi bekal terkait dinamika dunia kerja. Hasil yang diharapkan adalah mereka mendapatkan soft-skill terkait persiapan karir yang disinergikan pengalaman langsung di lapangan melalui magang. Kelompok yang menjadi pilot project pertama adalah mahasiswa yang menempuh magang selama 6 bulan di Badan Usaha Milik Negara (BUMN) bekerja sama dengan Forum Human Capital Indonesia (FHCI). Sebagai bentuk apresiasi, peserta pendampingan tidak hanya mendapatkan sertifikat dari BUMN juga dari UAJ dalam bentuk Satuan Kredit Partisipasi (SKP) Ilmiah sejumlah jam pertemuan.

Program ini disebut berkelanjutan karena pertemuan tidak hanya dilakukan sekali saja, melainkan selama periode magang, yaitu sebulan sekali, pada hari Sabtu minggu kedua. Dibutuhkan komitmen dari peserta dan pendamping untuk bertemu, dan mengikuti perkembangan yang dialami dari bulan ke bulan selama proses magang. Dampak pembelajaran akan lebih terlihat daripada hanya sekali pertemuan saja, terkesan hit and run.

Dalam proses berkelanjutan ini, peserta diajak untuk mengenal satu sama selain melalui metode peer sharing yang di dampingi oleh satu orang alumni sekaligus sebagai mentor. Kelompok pun selalu sama dari awal sampai akhir, untuk menimbulkan keterbukaan dalam sharing. Metode ini diberikan agar mereka saling menemukan masalah dan solusi bersama, bahkan dapat menjadi teman yang berjalan bersama selama proses magang.

Berikut adalah penjelasan teknis terkait proses pendampingan magang (Gambar 2).

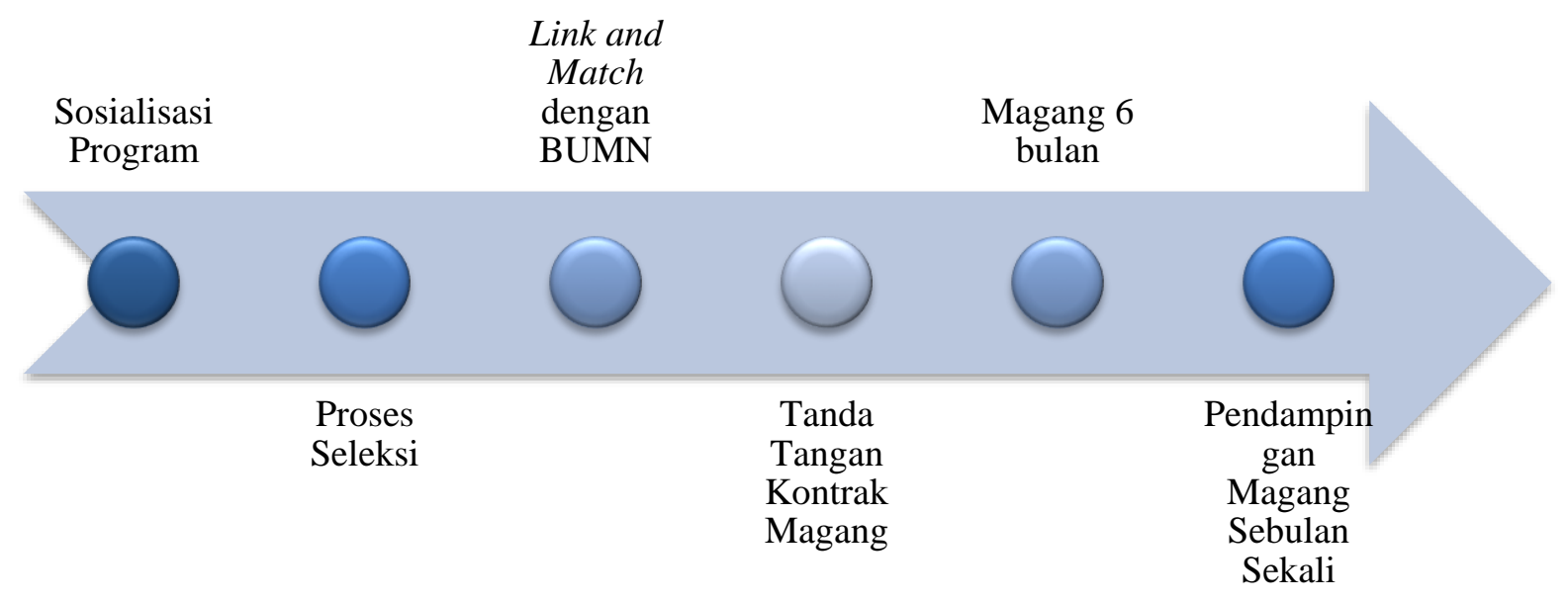

Gambar 2. Proses Program Pendampingan Magang Berkelanjutan.

Setelah melakukan tanda tangan kerja sama antara universitas dengan FHCI untuk program magang di BUMN, tahap berikutnya adalah sosialisasi program magang BUMN 
kepada mahasiswa. Proses sosialisasi ditempuh melalui media sosial dan jejaring, serta mengirimkan email kepada mahasiswa semester 5 dan yang lebih lanjut yang akan mengambil mata kuliah magang. Pendaftaran dilakukan secara daring, dengan mengisi formulir online yang disediakan. Setelah mengisi formulir tersebut, pendaftar akan dikirimkan syarat dokumen yang harus dilengkapi dan dikirimkan dapat melalui email atau mendatangi langsung kantor BKAK. BKAK akan menyeleksi dengan melihat nilai Indeks Prestasi Kumulatif yaitu minimal 3. Data peserta yang telah diseleksi dikirimkan ke FHCI untuk dicocokkan dengan kebutuhan jurusan dari BUMN (link and match). Setelah mendapatkan data link and match, tim BKAK menghubungi bagian Human Resouces Management (HRD) BUMN yang bersangkutan, misal dari Pertamina, Bank Mandiri, Bank BNI, dan lain-lain. Mahasiswa yang dinyatakan lolos dan cocok dengan kebutuhan BUMN diinformasikan dan menandatangani kontrak magang. Mahasiswa juga diwajibkan ikut pertemuan magang di kampus sebulan sekali pada Sabtu minggu kedua, sebagai bentuk pendampingan magang berkelanjutan. Pada akhir program, mereka diberi apresiasi dengan pemberian sertifikat penghargaan dari universitas (SKP) dan dari perusahaan. Proses pemberian ini pun dilakukan bersamaan dengan upacara dalam rangka peringatan hari kemerdekaan RI bersama mahasiswa baru di Kampus 3 BSD. Jumlah peserta yang mengikuti program ini, dari 200 pendaftar diseleksi menjadi 100, kemudian setelah dicocokkan dengan kebutuhan BUMN, maka muncul 50 nama, yang kemudian mengalami seleksi kembali karena harus melengkapi berkas, dan 20 mahasiswa yang bertahan hingga program pendampingan berakhir.

Materi yang diberikan saat program pendampingan adalah seperti tampak pada Tabel 1.

\begin{tabular}{|c|c|c|c|c|c|c|}
\hline No & Agenda & Event & Start & Finish & Method & $P I C$ \\
\hline \multirow[b]{2}{*}{1} & \multirow{2}{*}{$\begin{array}{l}1 \text { week before } \\
\text { internship }\end{array}$} & Boarding Time & $08: 30$ & $10: 00$ & Classroom & Internal Team \\
\hline & & Technical meeting & $10: 00$ & $12: 00$ & Meeting & $\begin{array}{l}\text { Event } \\
\text { Organizer }\end{array}$ \\
\hline \multirow{2}{*}{2} & \multirow{2}{*}{$\begin{array}{l}1 \text { month of } \\
\text { internship }\end{array}$} & Be proactive & $08: 30$ & $10: 00$ & Classroom & Trainer 1 \\
\hline & & Sharing session & $10: 00$ & $12: 00$ & Discussion & Mentor \\
\hline \multirow{2}{*}{3} & \multirow{2}{*}{$\begin{array}{l}2 \text { months of } \\
\text { internship }\end{array}$} & Resilience 1 & $08: 30$ & $10: 00$ & Classroom & Trainer 1 \\
\hline & & Sharing session & $10: 00$ & $12: 00$ & Discussion & Mentor \\
\hline \multirow{2}{*}{4} & \multirow{2}{*}{$\begin{array}{l}3 \text { months of } \\
\text { internship }\end{array}$} & Resilience 2 & $08: 30$ & $10: 00$ & Classroom & Trainer 2 \\
\hline & & Sharing session & $10: 00$ & $12: 00$ & Discussion & Mentor \\
\hline \multirow{2}{*}{5} & \multirow{2}{*}{$\begin{array}{l}4 \text { months of } \\
\text { internship }\end{array}$} & Integrity 1 & $08: 30$ & $10: 00$ & Classroom & Trainer 3 \\
\hline & & Sharing session & $10: 00$ & $12: 00$ & Discussion & Mentor \\
\hline \multirow{2}{*}{6} & \multirow{2}{*}{$\begin{array}{l}5 \text { months of } \\
\text { internship }\end{array}$} & Integrity 2 & $08: 30$ & $10: 00$ & Classroom & Trainer 4 \\
\hline & & Sharing session & $10: 00$ & $12: 00$ & Discussion & Mentor \\
\hline \multirow[t]{2}{*}{7} & \multirow{2}{*}{$\begin{array}{l}6 \text { months of } \\
\text { internship }\end{array}$} & $\begin{array}{l}\text { Assertive } \\
\text { Communication }\end{array}$ & $08: 30$ & 10:00 & Classroom & Trainer 5 \\
\hline & & Sharing session & $10: 00$ & $12: 00$ & Discussion & Mentor \\
\hline 8 & Closing & $\begin{array}{l}\text { Graduation } \\
\text { ceremony }\end{array}$ & $08: 00$ & $10: 00$ & Ceremony & $\begin{array}{l}\text { Event } \\
\text { Organizer }\end{array}$ \\
\hline
\end{tabular}

Tabel 1. Agenda Pertemuan Program Pendampingan Magang Berkelanjutan

Berdasarkan Tabel 1, terdapat pola yang sama, yaitu pada awal sesi diberikan materi tentang tiga atribut temuan terkait hal yang harus ditingkatkan dari calon lulusan. Materi yang menjadi perhatian khusus adalah tentang daya lenting dan integritas, karena dua bagian ini menjadi dasar dalam pengembangan karakter pribadi yang unggul. Oleh karena itu, kedua 
materi ini diberikan dalam dua kali pertemuan. Setiap sesinya dimulai dengan memberikan pre- dan post-test terkait materi, lalu input materi dari trainer. Pada akhir sesi, terdapat sesi tanya jawab. Sebelum masuk ke sharing session bersama mentor yang merupakan alumni, peserta diberi aktivitas permainan terkait materi, misal diberi kasus dalam kelompok, dan mereka diminta memecahkan kasus tersebut. Sebagai bahan sharing, mereka diminta menulis terlebih dahulu terkait beberapa pertanyaan yang diberikan, misal, apa yang saya ketahui tentang integritas, bagaimana saya menerapkan integritas di dalam proses magang, apakah saya pernah menghadapi masalah terkait integritas dan bagaimana saya mengatasinya? Ketiga pertanyaan ini dibagikan kepada anggota kelompok dengan bantuan mentor. Sejak pertemuan keempat, sharing dilakukan dengan metode coaching yaitu terdapat coach yang membantu memberikan pertanyaan untuk menggali apa yang mereka alami. Proses ini, disebut juga proses otoetnografis (Abraham, Azizah, \& Dhowi, 2017), dapat membantu mereka menemukan jawaban atas masalah yang ternyata ada di dalam diri mereka masing-masing.

Proses sharing dilakukan dalam kelompok yang sama tiap bulannya. Hal ini, untuk membantu keterbukaan mereka dalam sharing/ dengan orang yang sama setiap bulannya, kepercayaan akan muncul secara perlahan. Proses menjalin hubungan itu secara bertahap, seperti sebuah bawang merah yang dapat dikupas terus tiap lapisan, hingga pada inti bawang tersebut. Sama halnya seperti menjalin hubungan antarmanusia, dimulai dari lapisan pertama yaitu data diri, kemudian, lapisan berikutnya tentang hobi, makanan yang disuka, dan seterusnya. Selanjutnya, lapisan semakin dalam tentang opini, tujuan, dan lapisan berikutnya tentang keyakinan, misal agama, dan paling inti adalah konsep tentang dirinya (Griffin, 2012: 114-115). Hal ini sama dengan proses sharing yang dilakukan pada kelompok pendampingan magang berkelanjutan ini. Pada awalnya, mereka mampu sharing pada taraf mengenal temantemannya, kemudian masuk mengenal lebih dalam terkait apa yang teman-temannya suka, hingga akhirnya pada keterbukaan diri terkait masalah yang dihadapi selama magang. Misalnya, terdapat masalah salah satu teman yang merasa tidak diperhatikan oleh mentor di tempat magang, sehingga ia bingung mau mengerjakan apa selama magang. Ketika proses sharing berlangsung di pertemuan pendampingan magang, ia pun mampu mencurahkan perasaannya, dan mendapat peneguhan dari teman-teman serta mentor. Dengan demikian, ia menjadi lebih siap ketika mendapatkan masalah serupa.

Berikut adalah dokumentasi kegiatan (Gambar 3, Gambar 4, Gambar 5) program pendampingan karir berkelanjutan yang dijalankan dari bulan Februari-Agustus 2019.
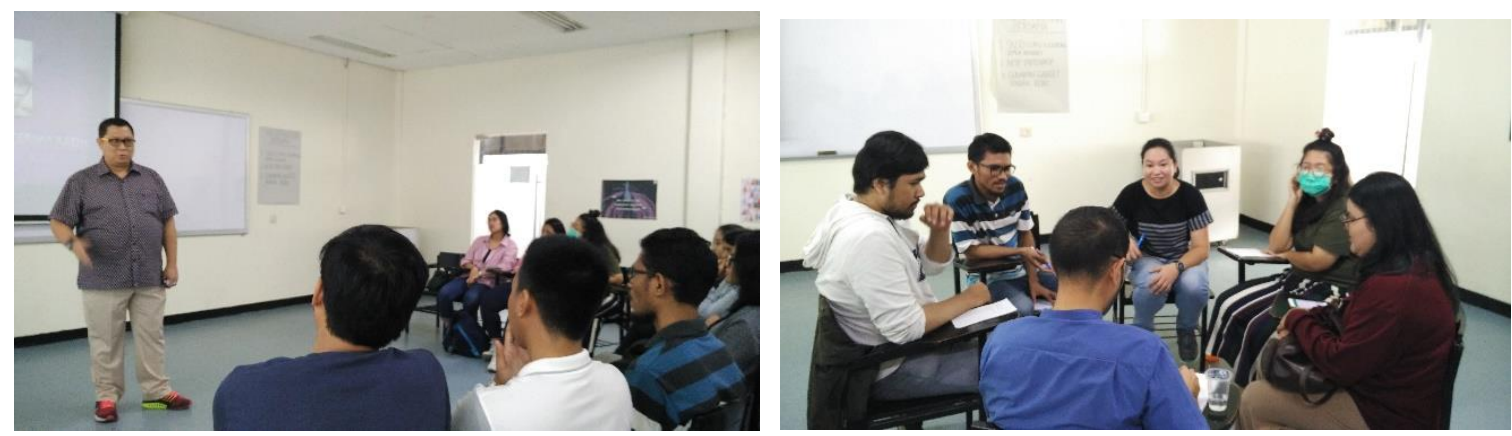

Gambar 3. Foto saat sesi tentang daya lenting disampaikan, kemudian dilanjutkan dengan aktivitas mendiskusikan kasus yang diberikan. 

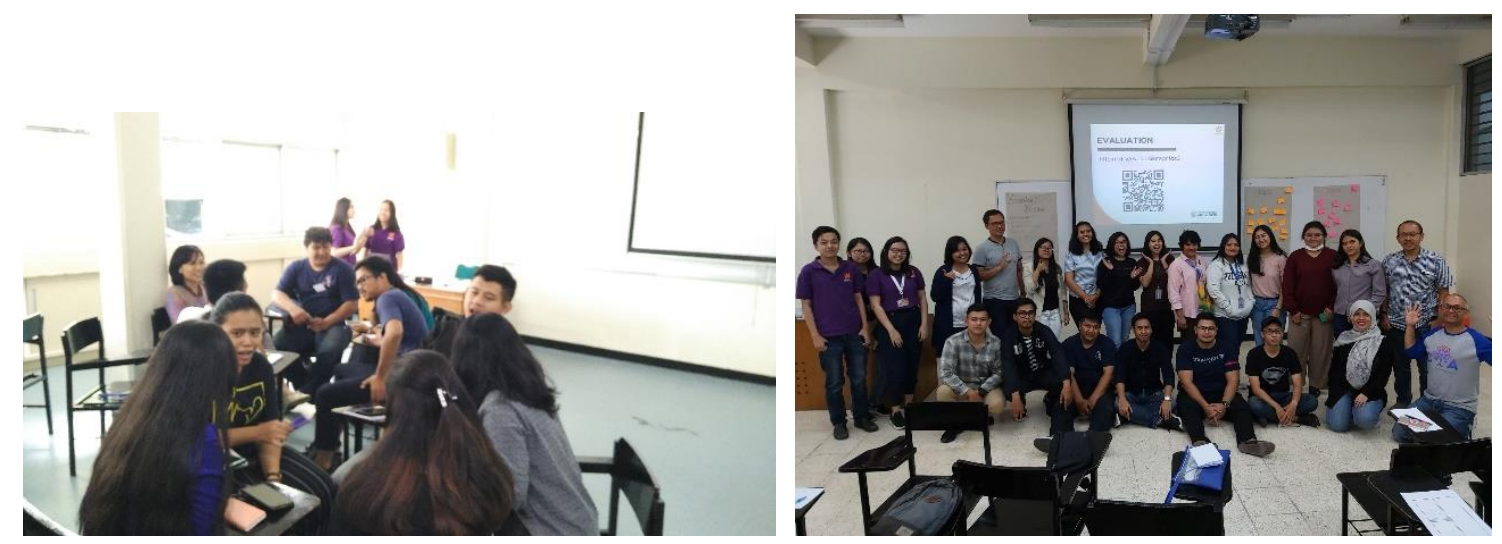

Gambar 4. Sesi sharing bersama kelompok dan mentor, kemudian diakhir acara, berfoto bersama dengan panitia dan peserta.

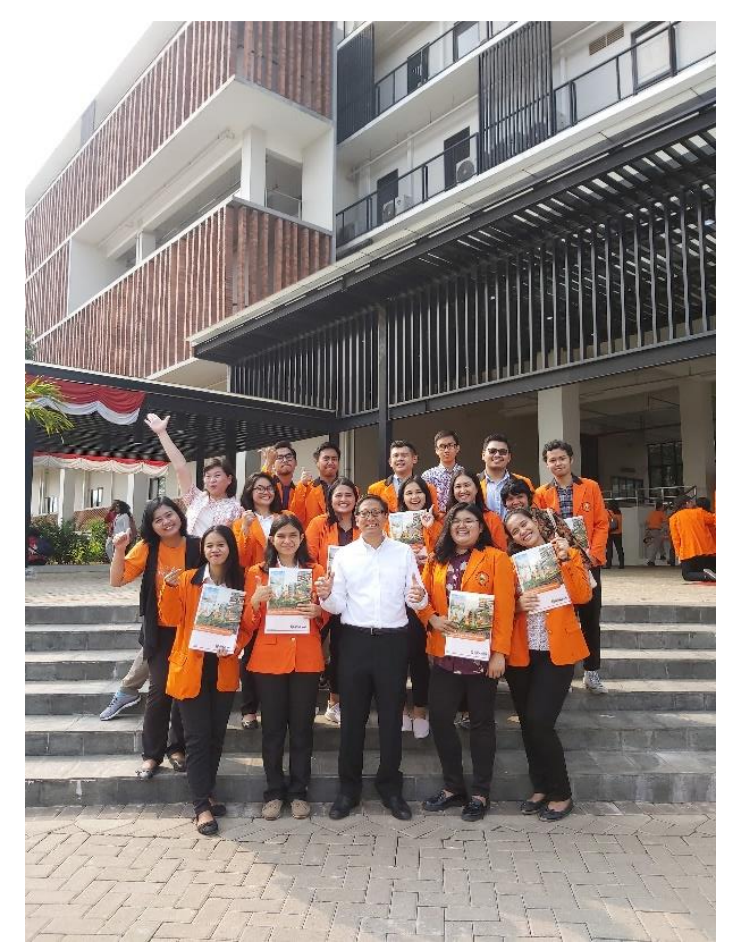

Gambar 5. Saat selesai upacara 17 Agustus 2019 memberikan apresiasi berupa sertifikat SKP.

Saat sesi akhir program pendampingan magang ini, para peserta diminta untuk memberikan evaluasi kegiatan, dan mereka semua setuju jika program ini bermanfaat untuk memberikan bekal selama magang dan persiapan karir. Oleh karena sebagian dari peserta saat proses magang sekaligus menempuh skripsi, dan saat magang selesai, beberapa dari mereka telah selesai skripsi. Beberapa ada yang tertarik untuk balik kembali bekerja di BUMN, ada pula yang ingin mencoba pekerjaan di perusahaan lainnya. 


\section{Kesimpulan}

Program pendampingan karir berkelanjutan "secara sandwich" dalam magang selama 6 bulan di BUMN ini memiliki beberapa keuntungan, kelemahan, peluang, dan ancaman berikut bagi pusat karir. Keuntungan yang dapat diraih adalah program ini adalah program pusat karir yang membantu mahasiswa mempersiapkan karir ke depan dengan pendampingan, dapat membentuk komunitas mahasiswa, sehingga memudahkan bagi pusat karir untuk talent scouting. Bagi mahasiswa, program ini dapat membantu mereka dalam mempersiapkan karir, dan mereka merasa tidak sendirian ketika magang. Hal ini karena ada teman-teman yang dikumpulkan dalam satu kegiatan untuk sharing, sehingga dapat membantu menemukan solusi bersama, atau sekadar saling meneguhkan satu sama lain. Bagi perusahaan atau users, program ini membantu mereka dalam menerima lulusan yang siap kerja, bahkan pusat karir dapat merekomendasikan beberapa nama potensial untuk bekerja di perusahaan rekanan.

Peluang dari program ini sangat besar, karena program ini dalam dikolaborasikan dengan perusahaan atau users sebagai bentuk training awal sebelum masuk ke dunia kerja. Bahkan, seleksi karyawan dapat dilakukan dari program ini, dengan melihat mahasiswa yang potensial sebelum lulus. Jika sudah lulus, mahasiswa tersebut dikontrak untuk bekerja. Isi program pendampingannya pun dapat disesuaikan dengan nilai yang ingin disasar oleh perusahaan atau users, namun tiga atribut AIR tetap menjadi dasar program.

Namun, program ini memiliki kelemahan sekaligus ancaman yaitu, membutuhkan waktu yang cukup panjang yaitu 6 bulan sehingga, komitmen dari panitia dan peserta dibutuhkan disini. Jika tidak, maka, program tidak akan berjalan dengan baik. Selain itu, untuk menggali komitmen dari peserta, diadakan reward dan punishment dalam bentuk informed consent yang ditandatangani peserta, misal total kehadiran 6 kali, izin hanya dilakukan satu kali saja; jika lebih dari sekali, peserta tidak akan mendapatkan sertifikat penghargaan. Hal ini telah dilakukan dan terbukti efektif pada komitmen peserta untuk hadir. Absensi menjadi hal penting disini. Hal yang menjadi ancaman adalah jika perusahaan atau users yang bekerja sama tidak memiliki komitmen. Maknanya, komitmen bersama adalah kunci keberhasilan program ini.

\section{Referensi}

Abraham, Juneman, Pane, Murty Magda. 2014. Corruptive Tendencies, Conscientiousness, and Collectivism. Procedia - Social and Behavioral Sciences, 153, 132-147. https://doi.org/10.1016/j.sbspro.2014.10.048

Azizah, Afifah, Abraham, Juneman, Dhowi, Bay. 2017. Pathway to Entrepreneurship University: An Autoethnography of Entrepreneurial Research Experience. Journal of Education and Learning (EduLearn), 11(3), 319-331. https://doi.org/10.11591/edulearn.v11i3.6704. Diakses dari http://journal.uad.ac.id/index.php/EduLearn/article/view/6704

Australian National University. 2017. Employability skills. Diakses dari http://www.anu.edu.au/students/careers-opportunities/careers/building-youremployability.

Buku Panduan Satuan Kredit Partisipasi Unika Atma Jaya tahun 2018.

Griffin, Em. 2012. A First Look of Communication Theory (Eight Edition). New York: McGraw Hill.

Litbang Kompas. 2017. Sejumlah profesi terancam hilang. Kompas, 3 Mei 2017. Diakses dari https://kompas.id/baca/utama/2017/05/03/sejumlah-profesi-terancam-hilang/ 
Tano, Shiela, Abraham, Juneman, Sitorus, Kartika. 2014. Student Athlete's Resilience: The Role of Perceived Coach's Resilience, Coaching Efficacy, and Sport's Masculinity. Proceedings of SGEM 2014 International Multidisciplinary Scientific Conferences on Social Sciences and Arts, 1, 405-412 (2014). https://doi.org/10.5593/sgemsocial2014/B11/S1.053. Diakses dari https://ssrn.com/abstract=2528796

Yorke, Mantz. 2004. Learning \& Employability. United Kingdom: The Higher Education Academy. 